\begin{tabular}{l} 
MATAPPA: Jurnal Pengabdian Kepada Masyarakat \\
Volume 2 | Nomor 2 | September |2019 \\
e-ISSN: 2614-6673 dan p-ISSN: $2615-5273$ \\
\begin{tabular}{|l|l|} 
(c) (1) This work is licensed under a Creative Commons Attribution \\
(1) International License
\end{tabular} \\
\hline
\end{tabular}

\title{
Pemanfaatan Sampah Organik Perkotaan Dalam Pembuatan Pupuk Organik Cair Menggunakan Dekomposer Mikroorganisme Lokal (Mol)
}

\author{
Mughni Latifah ${ }^{1}$, Khairun Nisaa ${ }^{2}$
}

\begin{tabular}{l}
\hline \hline Keywords : \\
Sampah Organik; \\
Perkotaan; \\
Pupuk Organik; \\
Dekomposer \\
Mikroorganisme Lokal \\
(MoL) \\
Corespondensi Author \\
${ }^{1}$ Bidang Manajemen, Jl. Perintis \\
Kemerdekaan Km 11, Fakultas \\
Perikanan, Universitas \\
Cokroaminoto Makassar, Sulawesi \\
Selatan, \\
Indonesia,mughniltfh@ gmail.com \\
2Bidang Perikanan, Jl. Perintis \\
Kemerdekaan Km 11, Fakultas \\
Perikanan, Universitas \\
Cokroaminoto Makassar, Sulawesi \\
Selatan, Indonesia, \\
nisauicha27@gmail.com
\end{tabular}

\section{History Artikel}

Received: 18-07-2019;

Reviewed: 25-07-2019;

Revised: 10-08-2019;

Accepted: 21-08-2019;

Published: 29-09-2019

\begin{abstract}
Abstrak. Program Kemitraan Masyarakat bertujuan untuk meningkatkan meningkatkan keterampilan mitra dalam pemanfaatan limbah organik rumah tangga dalam membuat pupuk organik untuk tanaman dan memecah permasalahan sampah khususnya limbah atau sampah organik masyarakat perkotaan kota Makassar. Kegiatan ini dimulai dari sosialisasi dan pelatihan pembuatan pupuk MOL dan mengolah limbah organik rumah tangga dalam komposter menjadi pupuk kompos cair siap pakai. Selanjutnya dilakukan pemberian bibit tanaman untuk aplikasi langsung hasil praktek pembuatan MOL. Pendampingan dilakukan dengan pengamatan perkembangan pembuatan pupuk MOL dan penggunaan komposter dilapangan. Kegiatan ini dilaksanakan sekitar 3 bulan mulai dari membina, mendampingi, serta memberikan arahan dalam pembuatan pupuk MOL dan penggunaan alat komposter dalam mengolah limbah organik menjadi pupuk. Kendala yang dihadapi selama melakukan kegiatan pendampingan adalah mitra masih mengalami kendala dalam tertib membuka tutup wadah penyimpanan MOL selama proses fermentasi untuk mencegah terjadinya penumpukan gas. Namun dengan adanya pendampingan, kendala-kendala yang dihadapi terkait teknik dan metode dapat terselesaikan.
\end{abstract}

Abstract. Aim of this Community Partnership Stimulus Program was to improve partner skills in utilizing household organic waste in making organic fertilizer for plants and to solve the problem of waste, especially organic waste in Makassar city. This activity was started from the socialization and training in making Local Microorganism (LoM) fertilizer and processing household organic waste in composters into ready-to-use liquid organic fertilizer (LoF). Furthermore, giving seedlings for direct application of the results of the practice of making LoF. Assistance is carried out by observing the development of Local Microorganism (LoM) fertilizer manufacturing and the use of composter in the field. This activity was carried out for about 3 months. It was started from fostering, assisting, and providing direction in making LoM and the use of composter equipment in processing organic waste into LoF. The obstacle faced during conducting the mentoring activities was that the partners were still experiencing difficulties in orderly opening and closing the LoM storage container during the fermentation process to prevent gas buildup. However, with the assistance, the obstacles encountered related to techniques and methods can be resolved. 


\section{PENDAHULUAN}

Kelurahan Barombong termasuk dalam wilayah Kecamatan Tamalate Kota Makassar dan memiliki wilayah terluas yaitu $7,34 \mathrm{~km}^{2}$ dengan jumlah penduduk sebesar 13.276 (Syamsuddin, 2018). Padatnya penduduk diwilayah tersebut menggiring pada banyaknya potensi sampah organik dan anorganik yang akan dihasilkan. Permasalahan sampah kerap kali menjadi permasalahan yang kompleks. Sampah merupakan salah satu faktor yang menyebabkan rusaknya lingkungan. Limbah padat dari buangan pasar dan pabrik atau perusahaan yang bergerak di bidang pengolahan bahan makanan cukup besar jumlahnya. Limbah tersebut salah satunya berupa limbah sayuran dan ikan yang hanya ditumpuk di tempat pembuangan dan menunggu pemulung untuk mengambilnya atau dibuang ke TPA jika tumpukan sudah meninggi. Penumpukan yang terlalu lama dapat menj adi ancaman tersendiri dimana dalam jangka pajang, mengakibatkan pencemaran dan bau yang tidak sedap.

Saat ini, pengelolaan aliran limbah perkotaan di negara-negara berkembang tidak dioptimalkan. Dalam banyak kasus, limbah ini dibuang tanpa penanganan di tempat pembuangan terbuka. Fakta ini menyebabkan masalah lingkungan dan kesehatan yang serius karena adanya kontaminan dan pathogen (JaraSamaniego, 2017). Melalui program PKMS ini, masyarakat dapat mengolah sampah menjadi pupuk cair yang dimanfaatkan oleh masyarakat setempat khususnya mitra. Mitra yang kami ajukan bertempat tinggal di Kelurahan Barombong secara administrasi termasuk dalam wilayah kecamatan Tamalate Kota Makassar. Mitra adalah pengusaha di bidang pengolahan hasil perikanan. Mitra mengembangkan usaha pengolahan rumput laut menjadi makanan. Limbah organik dari kegiatan produksi cukup banyak, selain itu, limbah rumah tangga dari sekitar mitra juga cukup banyak mengingat lokasi mitra berada di daerah padat penduduk.

Pemberdayaan kelompok mitra dilakukan guna meningkatkan perekonomian mitra, melalui pengembangan usaha produksi pupuk cair untuk tanaman yang dapat dijual kembali atau digunakan sendiri untuk tanaman sayuran dll. Selain itu juga, pemberdayaan mitra sebagai percontohan guna dapat merangsang masyarakat untuk berwirausaha. Terciptanya komunitas yang berdaya akan dapat menanggulangi kemiskinan.

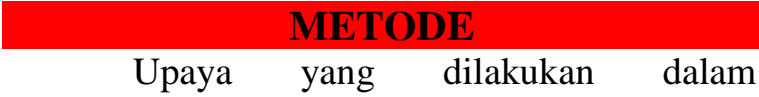

menanggulangi masalah sampah mitra dan masyarakat setempat, maka dilakukan pelatihan pembuatan MOL (mikroorganisme local) sebagai mikroba decomposer yang selanjutnya digunakan dalam mengolah sampah organik rumah tangga sehingga menghasilkan pupuk cair. Aadapun langkah-alngkah yang dilakukan antara lain :

1. Survey

Melakukan survey lokasi tempat

pengabdian, mendata kebutuhan alat dan

bahan yang dibutuhkan selama kegiatan

sosialisasi dan pelatihan

2. Perizinan pelaksanaan kegiatan

Kegiatan perizinan dilakukan dengan penandatanganan kerjasama bersama mitra Kelompok Mawar yang berisi kesediaan kelompok mitra dalam mengikuti pegiatan pelatihan dan pendampingan dalam pengolahan sampah atau limbah organik rumah tangga.

3. Tahap Persiapan Alat Komposter

Alat yang digunakan dalam mengolah sampah organik rumah tangga menjadi pupuk cair adalah komposter. Alat ini dibuat dari wadah drum atau ember yang dilengkapi dengan penutup. Bagian dalam wadah diberi saringan yang terbuat dari aluminiumsebagai pemisah antara sampah padat dan pupuk cair hasil fermentase mikroba decomposer (MOL).

4. Sosialisasi Kegiatan

Tahap sosialisasi dihadiri oleh Kepala Kelurahan Barombong Kota Makassar, serta kelompok mitra. Tahap ini dilakukan bertujuan untuk agar peserta memahami tujuan dari kegiatan pelatihan dan pendampingan serta manfaat yang akan diperoleh jika kegiatan ini berhasil dilaksanakan. Pada kegiatan sosialisasi juga peserta diberikan penjelasan mengenai tahapan yang akan dilakukan selama pelatihan pembuatan pupuk cair serta gambaran singkat tentang target pasar pupuk cair hasil pengolahan sampah dalam komposter.

5. Kegiatan Pelatihan Pembuatan Pupuk Cair Kegiatan pelatihan dan demonstrasi pembuatan pupuk cair dilakukan melalui simulasi dan diikuti oleh seluruh anggota kelompok mitra.

6. Pendampingan dan Monev

Setelah kegiatan utama maka akan dilaksanakan evaluasi terhadap kegiatan 
KMS yang telah dilaksanakan dengan beberapa kegiatan yang diantaranya evaluasi hasil pupuk yang diproduksi dan diaplikasikan pada tanaman sayur yang ditanam oleh masyarakat setempat degan melihat tingkat kesuburan tanaman yang ditanam.

\section{HASIL DAN PEMBAHASAN}

1. Alat komposter yang digunakan pada kegiatan PKMS ini berasal dari wadah volume 20 liter (Gambar 1). Pada bagian dalam wadah diberi saringan yang terbuat dari aluminium untuk memisahkan sampah organik dengan pupuk cair hasil composer dari MOL (microorganism local) (Gambar 2). Pada bagian samping bawah wadah dipasangkan keran yang digunakan untuk mengeluarkan pupuk cair yang dihasilkan.

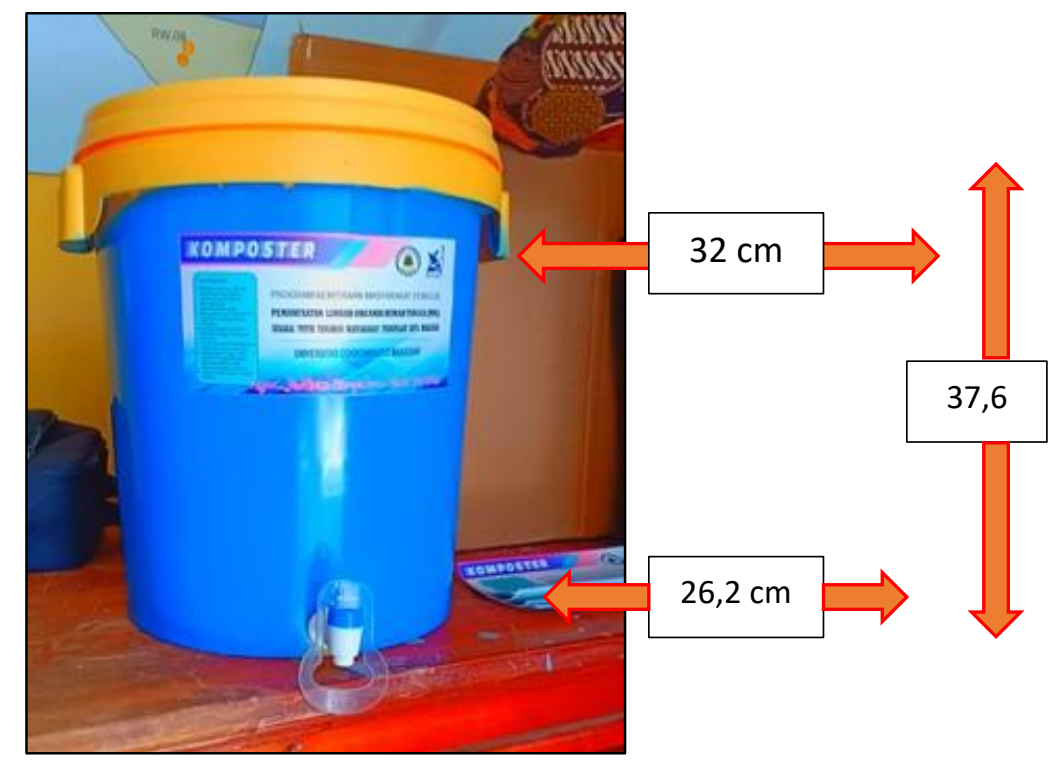

Gambar 1. Alat Komposter berukuran diameter atas $32 \mathrm{~cm}$, diameter bawah 26,2 cm, dan tinggi 37,6 $\mathrm{cm}$ dengan volume sekitar 20 Liter

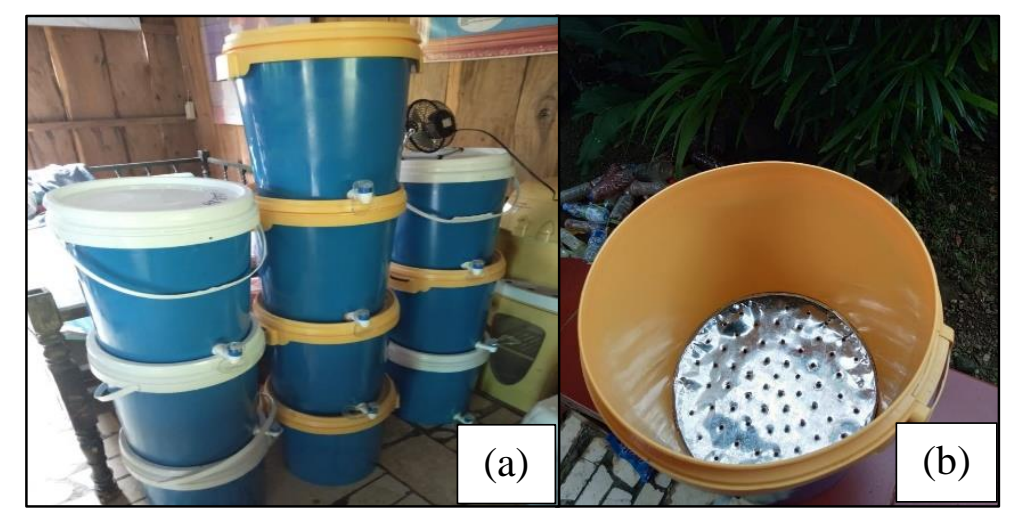

Gambar 2. Alat komposter. (a) komposter tampak luar; (b) komposter tampak dalam

2. Kegiatan sosialisasi dan penyuluhan memaparkan manfaat pengolahan limbah organik rumah tangga dalam membuat pupuk cair yang dapat digunakan untuk menyuburkan tanaman. Kegiatan ini dihadiri oleh kelompok Mawar sebagai kelompok mitra yang berasal dari Kelurahan
Barombong Kota Makassar dan Kepala Kelurahan Barombong, Kecamatan Tamalate Kota Makassar. Pada kegiatan ini juga dilakukan pemaparan terkait tahapan pembuatan MOL dan pengolahan limbah organik rumah tangga dalam komposter hingga dapat menghasilkan pupuk cair (Gambar 3). Penyerahan alat komposter 
dilakukan di kantor Lurah dihadiri oleh Ibu Sekertaris Lurah (Gambar 4). Komposter diberikan beserta alat penyemprot cairan
MOL dan corong untuk memudahkan pengisian MOL ke dalam wadah semprotan.

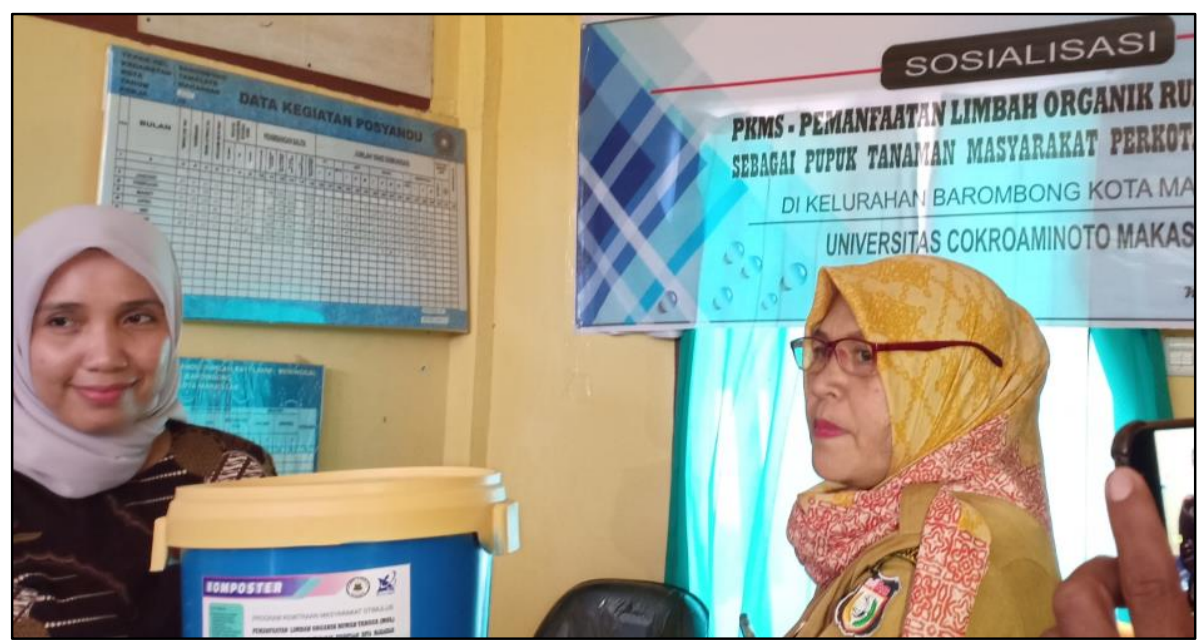

Gambar 3. Penyerahan alat komposter

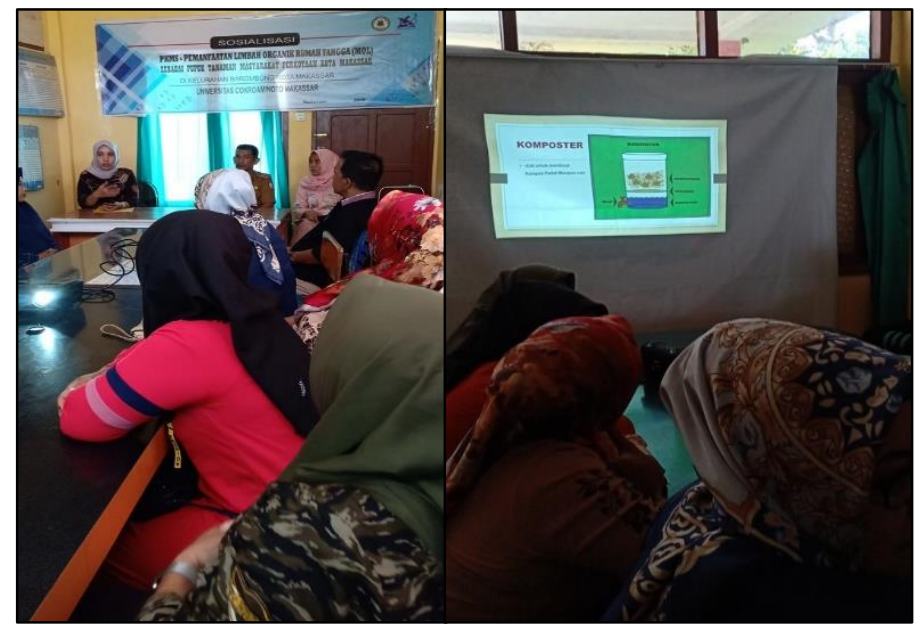

Gambar 4. Pemaparan materi teknik pengolahan sampah organik rumah tangga

3. Kegiatan pelatihan dan demonstrasi dihadiri oleh seluruh anggota Kelompok Mawar atau kelompok Mitra. Pada proses pembuatan MOL sebagai mikroba decomposer yang akan digunakan pada proses pembuatan pupuk cair dalam komposter, bahan-bahan yang digunakan antara lain bonggol pisang, daun kelor, buah bila, rebung, air cucian beras, air kelapa, dan gula merah sebagai pengganti molase. Bahan-bahan tersebut dibagi beberapa kelompok dengan komposisi bahan antara lain :

a. $1 \mathrm{~kg}$ bonggol pisang $+1 \mathrm{~kg}$ gula merah (dicairkan) +200 gram daun kelor +1 liter air kelapa +1 liter air bekas cucian beras

b. $1 \mathrm{~kg}$ bonggol pisang $+1 \mathrm{~kg}$ gula merah (dicairkan) +200 gram rebung +1 liter air kelapa +1 liter air bekas cucian beras c. $1 \mathrm{~kg}$ bonggol pisang $+1 \mathrm{~kg}$ gula merah (dicairkan) $+1 \mathrm{~kg}$ buah bila +1 liet air kelapa +1 liter air bekas cucian beras

Kelompok bahan-bahan tersebut dihaluskan menggunakan blender dan dimasukkan ke dalam botol plastic kemudian ditutup rapat (Gambar 5). Fermentase dilakukan selama kurang lebih 2 (dua) minggu (Gambar 6). Setelah proses fermentasi selesai, maka terbentuklah pupuk MOL. MOL tersebut digunakan oleh kelompok mitra dalam mengolah sampah organik menjadi pupuk cair dalam komposter. Masing-masing anggota kelompok diberikan bahan dan alat komposter untuk dipraktekkan di rumah masingmasing. Selama proses fermentase sampah organik hingga menghasilkan pupuk cair, disarankan mitra membuka wadah komposter setiap hari untuk menghindari penumpukan gas dalam wadah. 


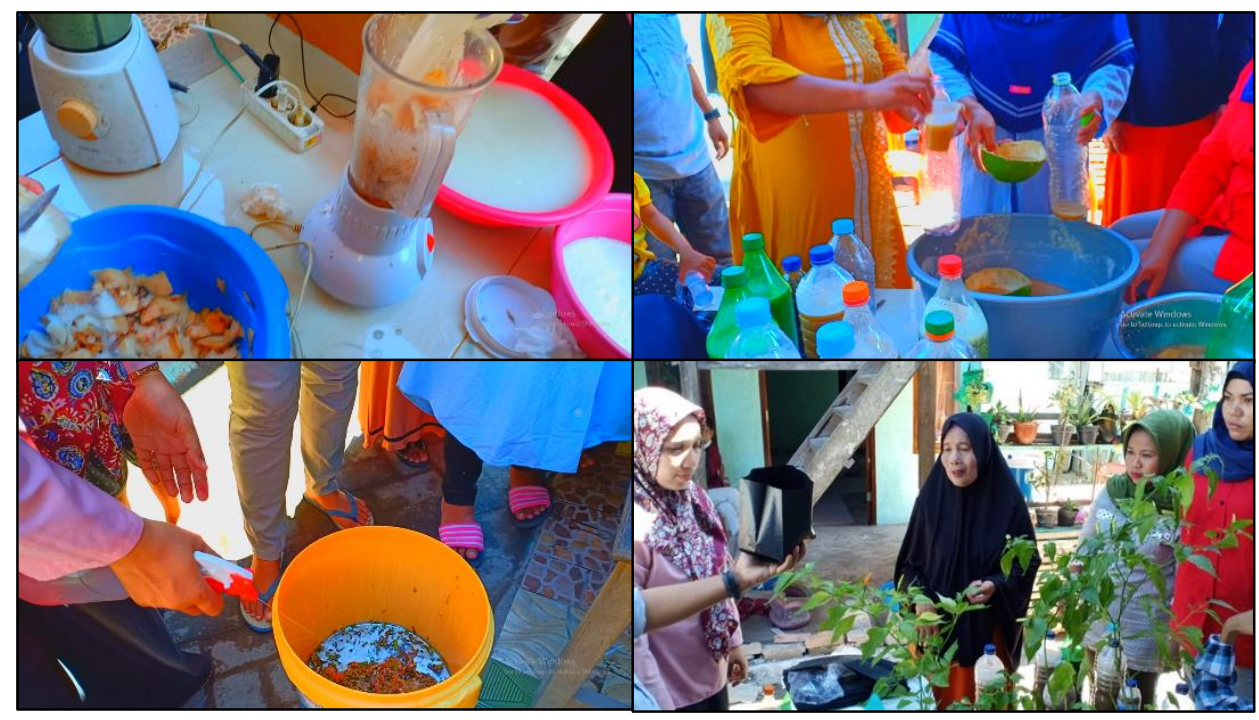

Gambar 5. Rangakian kegiatan pelatihan pembuatan cairan Microorganisme Local (MOL) dan metode penggunaan cairan MOL sebagai bioaktivator dalam pengolahan limbah organik rumah tangga dalam komposter menjadi pupuk cair

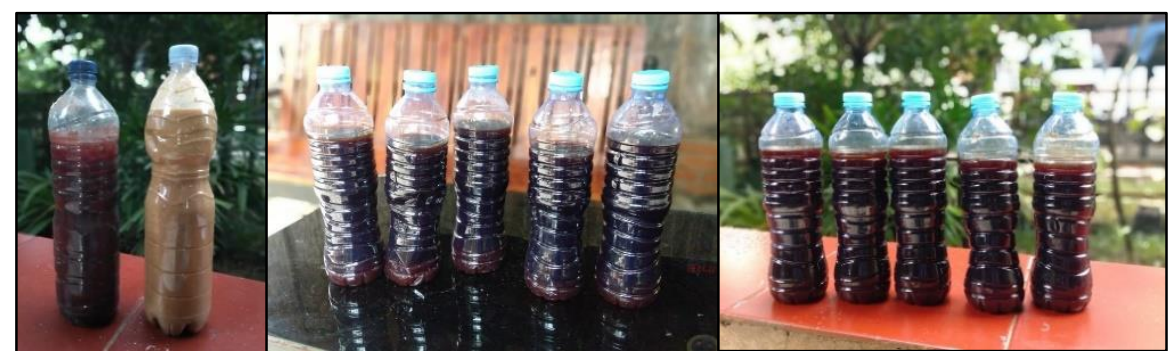

Gambar 6. Cairan Microorganisme Local (MOL) yang telah mengalami proses fermentase dan siap pakai sebagai bioaktivator pengolahan sampah organik rumah tangga. Perbedaan warna mengindikasikan perbedaan bahan baku dan jenis mikroba yang terkandung

4. Kelompok Mitra diberikan bantuan bibit tanaman cabe dan strawberry varietas dataran rendah untuk mempermudah proses aplikasi pupuk cair yang dihasilkan. Selain itu, Tim juga membagikan cairan MOL yang telah mengalami proses fermentase dan siap diaplikasikan ke sampah atau limbah organik rumah tangga kepada masing-masing anggota kelompok Mitra untuk mempercepat proses aplikasi ke sampah organik dan sebagai contoh bagi Mitra (Gambar 6).

5. Metode aplikasi MOL juga dijelaskan pada saat pelatihan. Cairan MOL diencerkan dengan perbandingan 1: 10 dengan air, selanjutnya dimasukkan ke dalam wadah penyemprotan dan disemprotkan ke dalam wadah komposter yang telah berisi sampah atau limbah organik. Selanjutnya pengecekan pupuk cair dilakukan dengan membuka keran yang terdapat pada bagian bawah komposter. Pupuk cair yang dihasilkan ditampung dalam wadah botol plastik. dapat digunakan untuk pupuk tanaman cabe dan strawberry yang telah diberikan ke Mitra. Bila hasilnya cukup banyak, Tim menyarankan agar pupuk tersebut dikemas rapih sehingga dapat dijual dan mitra dapat memperoleh penghasilan tambahan. 


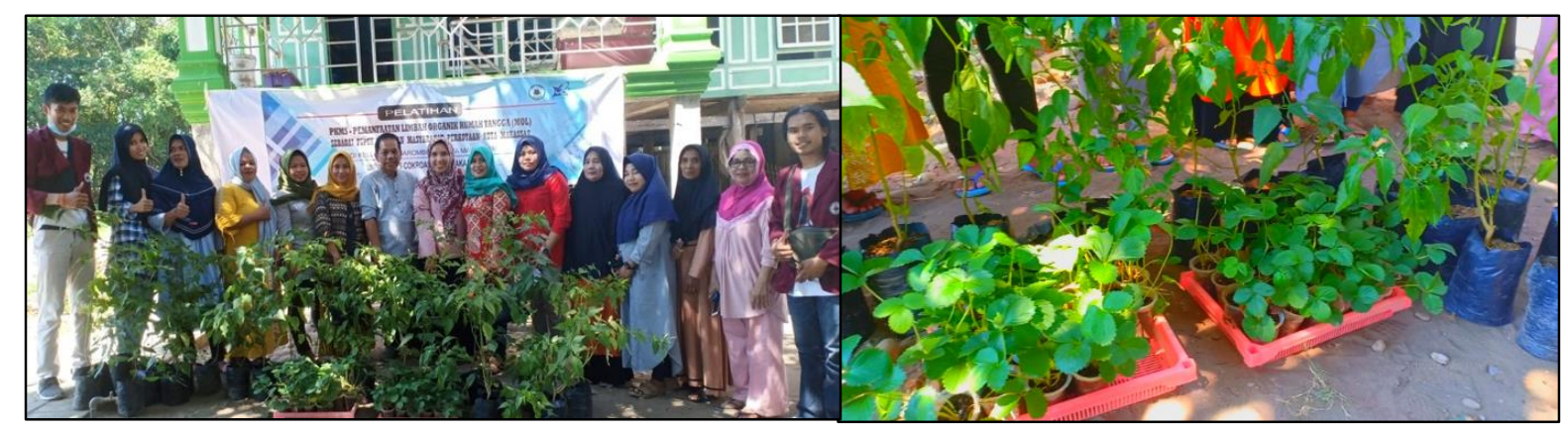

Gambar 6. Penyerahan bantuan bibit tanaman cabe dan strawberry kepada kelompok mitra

Kendala yang dihadapi selama proses pembelajaran pembuatan MOL dan pupuk cair adalah proses pembiasaan membuka tutup wadah penyimpanan secara rutin setiap hari untuk mengeluarkan gas selama proses fermentase yang tidak tertib, sehingga ada beberapa anggota yang alat dan botol penyimpanan MOL mengalami ledakan kecil. Namun ada beberapa mitra yang berhasil membuat pupuk cair walaupun jumlahnya belum banyak (Gambar ). Pupuk cair yang dihasilkan oleh anggota kelompok mitra juga berhasil diaplikasikan ke tanaman Lombok dan strawberry, sehingga tumbuh subur dan mengahsilkan buah baik tanaman strawberry dan juga Lombok (Gambar.

$$
\text { Mikroorganisme Lokal (MOL) }
$$

merupakan larutan yang terbuat dari bahan-bahan alami. MOL berfungsi sebagai media hidup dan berkembangnya mikroorganisme yang berfungsi untuk mempercepat penghancuran bahan organik. MOL dapat juga disebut sebagai bioaktivator yang terdiri dari kumpulan mikroorganisme lokal dengan memanfaatkan potensi sumber daya alam setempat. Selain itu, MOL juga dapat berfungsi sebagai perombak bahan organik dan sebagai pupuk cair melalui proses fermentasi (Budiyani dkk. 2016). Menurut Roeswitawati et al. (2018), microorganisme local (MOL) adalah kumpulan mikroorganisme yang dapat dibudidayakan, yang berfungsi sebagai starter dalam membuat pupuk organik cair. Lebih lanjut dijelaskan bahwa, pupuk organik dalam bentuk cair tersebut diperoleh dari proses dekomposisi bahan organik dari limbah sayuran, buangan hewan dan manusia yang mana bahan tersebut mengandung lebih dari satu elemen.

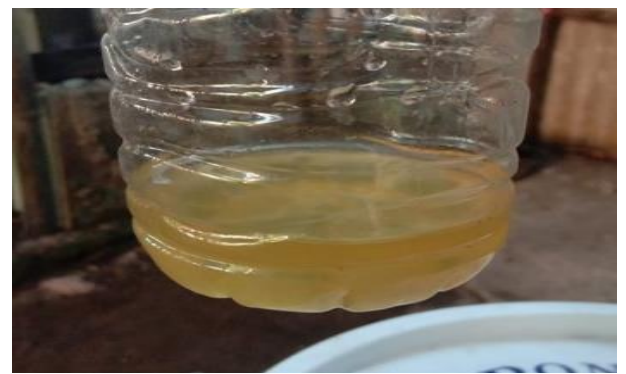

Gambar 7. Pupuk organik cair siap pakai hasil olahan sampah organik menggunakan bakteri pengurai MOL

Bonggol pisang yang digunakan sebagai bahan utama dalam pembuatan MOL dikarenakan bonggol pisang mengandung gizi yang cukup tinggi. Kandungannya antara lain karbohidrat (66\%), mempunyai kandungan kadar protein $4,35 \%$, sumber mikroorganisme pengurai bahan organik atau dekomposer (Munadjim, 1983 dalam Ole 2013). Pemanfaatan MOL selain mempermudah petani mendapatkan pupuk pengganti pupuk bahan kimia, proses pembuatan yang cukup singkat yaitu sekitar 2 minggu karena sifatnya sebagai bioaktivator. Menurut Widjajanto et al (2017), MOL didominasi oleh bakteri Lactobacillus plantarum, L. pentosus, dan L.brevis. Seluruh bakteri tersebut memegang peranan penting dalam meproduksi pupuk organik cair dan sangan direkomendasikan menggunakan sumber yang $100 \%$ buah dan $100 \%$ sayuran dalam pembuatan MOL.

Menurut Raja et al. (2012), buah-buahan dan sayuran menyediakan kondisi ideal untuk kelangsungan hidup dan pertumbuhan berbagai jenis mikroorganisme. Mikroorganisme membutuhkan sumber energi seperti C, N, K, dan unsur-unsur minor yang penting untuk membuat enzim dan aktivitasnya. Bakteri, actynomicetes, dan jamur dari tumpukan kompos seperti makhluk hidup lainnya membutuhkan karbon dari karbohidrat dan nitrogen dari protein dalam bentuk substrat kompos yang mengalami 
pertumbuhan dan reproduksi. Semua mikroba harus memiliki akses ke pasokan elemen yang dibuat oleh sel. Berdasarkan hasil penelitian tentang pengaruh bahan baku MOLterhadap kualitas Bungan yang dihasilkan diketahui bahwa MOL dari sampah buah-buahan memberikan pengaruh yang lebih baik terhadap variabel diameter dari bunga, bobot basah bunga, dan bobot basah tanaman brokoli dibanding dengan MOL yang berbahan dasar pisang (Roeswitawati, 2018).

Pengolahan sampah rumah tangga dilakukan dengan pemilahan sampah terlebih dahulu dilingkungan rumah tangga sendiri dengan pemilahan sampah organik dan anorganik. Sehingga pengolahan sampah dapat lebih mudah untuk diolah karena pengolahan sampah organik pengolahannya dapat dibuat menjadi berbagai alternatif seperti pupuk organik cair dan padat, biogas dan bahan bakar (Marlinda, 2015).

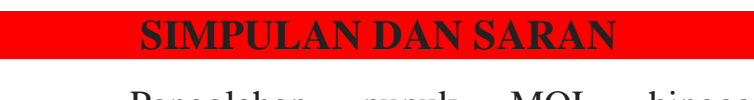

Pengolahan pupuk MOL hingga pengolahan sampah organik dalam komposter menjadi pupuk organik dapat menjadi alternative dalam menekan penggunaan pupuk kimia yang dapat menurunkan kualitas lingkungan, selain itu juga dapat menekan jumlah buangan limbah organik rumah tangga, dan menjadi salah satu peluang usaha baik dalam penjualan pupuk organik dan produk sayuran dan buah organik yang dihasilkan dari penggunaan pupuk organik tersebut.

Berdasarkan hasil sosialisasi dan pendampingan mitra selama kegiatan pengabdian kepada masyarakat, maka disarankan untuk melaksanakan kegiatan pelatihan dan pendampingan dalam pembuatan bioaktivator MOL disertai dengan metode pemanfaatannya dalam mengolah sampah organik sehingga kelompok binaan lebih paham terhadap proses dan mengetahui manfaat penggunaan MOL pada sampah organik.

Budiyani, N.K., Soniari, N.N., Sutari, N.W.S. 2016. Analisis Kualitas Larutan Mikroorganisme Lokal (MOL) Bonggol Pisang . E-Jurnal Agroekoteknologi Tropika. 5(1) : 63-72

Harahap, E.F. 2012. Pemberdayaan Masyarakat Dalam Bidang Ekonomi Untuk
Mewujudkan Ekonomi Nasional Yang Tangguh Dan Mandiri. Jurnal Manajemen dan Kewirausahaan, Pemberdayaan Masyarakat Dalam Bidang Ekonomi Untuk Mewujudkan Ekonomi Nasional Yang Tangguh Dan Mandiri Vol. 3(2): 78 - 96

Jara-Samaniego J, Pe'rez-Murcia MD, Bustamante MA, Paredes C, Pe'rezEspinosa A, Gavilanes-Tera'n I, et al. 2017. Development of organic fertilizers from food market waste and urban gardening by composting in Ecuador. PLoS ONE 12(7): e0181621. https://doi.org/10.1371/journal. pone. 0181621

Lepongbulan, W., Tiwow, V.M.A., dan Diah, A.W.M. 2017. Analisis unsur hara pupuk organik cair dari limbah ikan mujair (Oreochromis mosambicus) danau lindu dengan variasi volume mikroorganisme lokal (MOL) bonggol pisang. J. Akad. Kim. 6(2): 92-97

Marlinda. 2015. Pengaruh penambahan bioaktivator EM4 dan promi dalam pembuatan pupuk cair organik dari sampah organik rumah tangga. Konversi $4(2): 1-6$

Purwendro, D. dan Nurhidayat, T. 2007. Pembuatan Pupuk Cair. PT Gramedia Pustaka Utama. Jakarta.

Ole, M.B.B. 2013. Penggunaan Mikroorganisme Bonggol Pisang (Musa Paradisiaca) Sebagai Dekomposer Sampah Organik. Jurnal. Universitas Atma Jaya Yogyakarta Fakultas Teknobiologi Program Studi Biologi.

Raja MM, Raja A, Hajee MS, and Mohamed S. 2012. A Screening of bacterial compost from spoiled vegetables and fruits and their physiochemical characterization International Food Res. J. 19 (3): 11931198.

Roeswitawati, D., Ningsih, Y. U., Muhidin. 2018. The Effect of Local Microorganism (MOL) Concentration of Banana Hump and Fruit Waste on the Growth and Yield of Broccoli Plants (Brassica 
MATAPPA: Jurnal Pengabdian Kepada Masyarakat.

oleracea). Advances in Engineering

Research, vol. 172: 310-314

Widjajanto, D.W., Purbajanti, E. D., Sumarsono, Utama, C.S. 2017. The Role of Local Microorganisms Generated from Rotten Fruits and Vegetables in Producing Liquid Organic Fertilizer. J Applied Chem. Sci. 4: 325-329. DOI: http://doi.org/10.22341/jacson.00401p3 $\underline{25}$ 